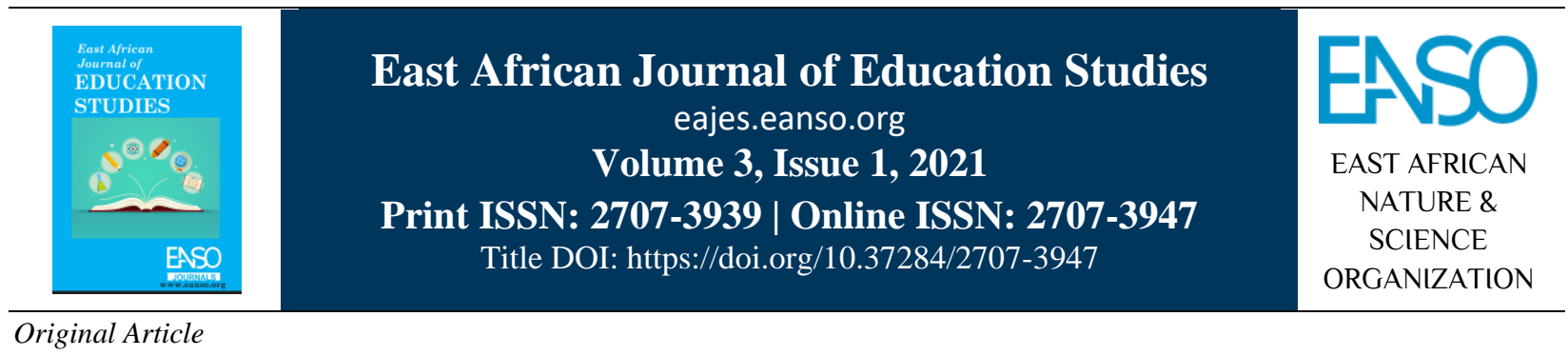

\title{
Female Students Participation in Technical Vocational Education and Training in West Pokot County, Kenya
}

\author{
Nelly Andiema, $P h D^{* 1}$ \& Echaune Manasi, $P h D^{1}$ \\ $1^{*}$ Lecturer, Department of Psychology and Early Childhood Education, Kibabii University, P. O. Box 307, Bungoma, Kenya. \\ * ORCID: https://orcid.org/0000-0001-9165-3370; Correspondence Email: nandiema@kibu.ac.ke.
}

Article DOI: https://doi.org/10.37284/eajes.3.1.314

\section{Date Published: ABSTRACT}

07 April 2021 Quality and affordable technical vocational education and training are one of the United Nations Sustainable Development agenda items for ensuring equal

Keywords: access to education for all women and men by the year 2030. This means that all women in the country need to have relevant skills for employment, job

Female, creation and entrepreneurship. Data from West Pokot County, Kenya

Quality, department of technical and vocational education show the number of female

Vocational,

Education, students being admitted in vocational training centres for the past five years has remained low. Whereas the government of Kenya has viewed TVET as a critical element of attaining Sustainable Development Goal and Kenya's

Training, Vision 2030 goals, the number of female students graduating from vocational Access. training and being absorbed in the job market remains low. This study looks at enrolment trends for female students in vocational training centres and further examines factors discouraging female students from joining vocational training institutions (VTCs). To collect data, interviews and documentary evidence were used. The respondents for the study involve managers of selected VTCs in West Pokot County. Analysis of data was done through qualitative and quantitative methods. The study found out that the distribution of students in all public VTCs in West Pokot County favoured the male gender over female students. For women enrolled in various programmes, only $45.0 \%$ fully completed their programme. It was found out that courses offered in VTCs tend to attract more male students compared to female ones. The distribution of the teaching workforce in VTCs was found to be male-dominated and therefore, female students did not have role models to look up to. The research also found out that majority of girls who were unable to proceed to secondary and tertiary education were not aware of the opportunities available in VTCs in the county. The paper concludes that social-cultural factors, lack of role models and 
poverty were some of the barriers affecting female students' participation in vocational education and training. The paper suggests more work needs to be done by all stakeholders to ensure that courses offered in VTCs are attractive to female students, remove social, cultural and physical barriers which prevent female students from enrolling and completing vocational training in West Pokot County, Kenya.

\begin{abstract}
APA CITATION
Andiema, N., \& Manasi, E. (2021). Female Students Participation in Technical Vocational Education and Training in West Pokot County, Kenya. East African Journal of Education Studies, 3(1), 61-69. https://doi.org/10.37284/eajes.3.1.314.
\end{abstract}

\title{
CHICAGO CITATION
}

Andiema, Nelly, and Echaune Manasi. 2021. "Female Students Participation in Technical Vocational Education and Training in West Pokot County, Kenya". East African Journal of Education Studies 3 (1), 61-69. https://doi.org/10.37284/eajes.3.1. 314.

\section{HARVARD CITATION}

Andiema, N. and Manasi, E. (2021) "Female Students Participation in Technical Vocational Education and Training in West Pokot County, Kenya”, East African Journal of Education Studies, 3(1), pp. 61-69. doi: 10.37284/eajes.3.1. 314.

\section{IEEE CITATION}

N. Andiema, and E. Manasi, "Female Students Participation in Technical Vocational Education and Training in West Pokot County, Kenya”, EAJES, vol. 3, no. 1, pp. 61-69, Apr. 2021.

\section{MLA CITATION}

Andiema, Nelly, and Echaune Manasi. "Female Students Participation in Technical Vocational Education and Training in West Pokot County, Kenya". East African Journal of Education Studies, Vol. 3, no. 1, Apr. 2021, pp. 61-69, doi:10.37284/eajes.3.1.314.

\section{INTRODUCTION}

Education is an important tool for a country's development as it is key to social, economic, political and technological development (Republic of Kenya, 2007). This means that every person (irrespective of gender) has an equal right to education as outlined by various international conventions (Education for All, Universal Declaration of Human Rights, among others). Over the years, the issue of girl child access to basic and tertiary education level has been a challenge affecting developing countries in sub-Saharan Africa (United Nations, 2015a). There is a saying which says that 'if you educate a girl, you educate and transform the community or nation'. This means that in African societies, the education of girls is critical for societal development. To address the barriers that prevent women from accessing education, the global bodies (United Nations associated organisations, African Union, Forum for African Women Educationists) have been at the forefront in advocating for equality of all to quality education (Ngugi \& Muthima, 2017). The United Nations Sustainable Development Agenda urges member nations to ensure that social, economic, educational and political barriers are removed for women to access gender equality (United Nations, 2015b). One of the resolutions (No. 6) passed during Addis Ababa Action Agenda in 2015 was that achieving gender equality, empowerment of women and girls and full realisation of their human rights are essential to the achievement of sustainable development and equitable economic growth (United Nations, 2015a).

The Sustainable Development Goal (SDG) Agenda 4 on Education, Target 4.3, seeks to ensure equal access for all men and women to affordable and quality technical, vocational and tertiary education by the year 2030 . This is justified by the fact that the majority of countries across the world have appreciated the importance of technical, vocational, education and training towards social-economic development (Institute of Economic Affairs, 2017). Kenya, in particular, aims to become a middleincome economy by the year 2030 (Republic of Kenya, 2007), and this can only be realised when the TVET sector produces quality and competent graduates. Nevertheless, UNESCO (2016) analysis 
showed that girls are still denied access (including right) to education across many countries worldwide. A review of studies conducted around the world shows that the TVET sector is mainly biased with few women provided the opportunity to pursue various courses which some years before were considered to be masculine (Azubuike, 2011). This discrimination in technical and vocational institutions is also evident in the job market, where gender inequalities are evident (International Labour Organisation, 2015). In the TVET sector, the rate of girls' students' participation has been a thorny issue from several studies conducted in the African continent.

Research by Adewale and Adhuze (2017) in Nigeria found out that low enrolment of female students in TVET courses. Surprisingly, they found out that no student had registered for the following craft and artisans' courses; painting, decoration, plumbing and pipefitting, carpentry and tiling. Another research by Lugga and Umoh (2018) discovered that the strategic role of TVET institutions in the empowerment of women was still grossly undermined and available capacities were underutilised in most sub-Saharan African countries. In Kenya, Ngugi and Muthima (2017) noted that despite the progress made in enhancing access, equity, retention, quality, completion rates and gender parity in education and training, the TVET subsector continues to experience low female enrolment in Science, Technology, Engineering and Mathematics (STEM) based courses. For instance, data from the Ministry of Education showed that in the year 2012, 60.5\% of total enrolments in TVET were male while $39.5 \%$ were female; in 2013, $59.49 \%$ were males while $40.51 \%$ were female and in $2014,60.59 \%$ were male, and $39.41 \%$ were female for the whole country (Ngugi \& Muthima, 2017). In West Pokot County 2010, enrolment data from public and private vocational training centres (formerly youth polytechnics) showed that girls faced challenges in enrolling in artisans and crafts courses as their number was low (Patrick, Maureen \& Lucas, 2015). The paper, therefore, investigates whether the trend in enrolment has changed from 2016 to 2010 in vocational education and training in West Pokot County.

\section{Problem Statement}

Technical vocational education and training aim to provide requisite skills and build human abilities in science, technology, engineering and mathematics fields (Opwora, 2013). As the country gears towards attaining Vision 2030 goals and SDG agenda, gender equality is essential. Women and girls must enjoy equal access to quality education, economic resources and political participation as well as equal opportunities with men and boys for employment, leadership and decision-making at all levels (UNESCO, 2016). This is because the skills that are acquired from vocational training prepare students for the future job market (formally or informally). Therefore, the government of Kenya identified that vocational training centres offered the opportunity to boys and girls who failed to proceed to secondary schools or colleges to acquire competitive skills and knowledge for gainful employment. Further, vocational education does not discriminate based on one's gender or marital status as learning mainly takes place through practical and on-field experiences. Despite the introduction of vocational education to equip boys and girls with skills, Serem (2014) research in Nandi County observed that female students are significantly underrepresented in vocational training centres (VTCs). This paper investigated the participation of girls in technical, vocational education and training in public VTCs in West Pokot County, Kenya.

\section{MATERIALS AND METHODS}

This study was conducted in West Pokot County, Kenya. The targeted 6 public vocational training centres; Kapenguria, Kodich, Ortum, Sigor, Sina and Chepareria. They are spread across the county in four sub-counties. The study population were the six managers of the vocational training institutions. Considering the study was conducted during schools' closure, it was impossible to get female students as respondents for the study. This research was a mixed-method one involving quantitative and qualitative approaches. Data collection was done through a document collection sheet and interview with managers. The data collection sheet was used to collect information on; number of teaching staff, enrolment and completion rate from the year 2016 to 2020. This was done so that the research can observe the trends and make deductions on them. 
Furthermore, the researcher conducted an interview (via the phone) with managers of 6 public VTCs to understand the dynamics associated with female students' participation in vocational training programmes in their institutions. The data collected has been analysed using descriptive statistics (frequencies, percentages and means) and qualitatively through the content analysis method as presented in the next sub-sections.

\section{RESULTS AND DISCUSSIONS}

\section{Distribution of Tutors in Vocational Training Centre}

The researcher conducted an analysis of tutors' distribution according to age from the year 2016 to 2020 .

Figure 1: Distribution of male and female tutors in VTCs in West Pokot County form 2016-2020

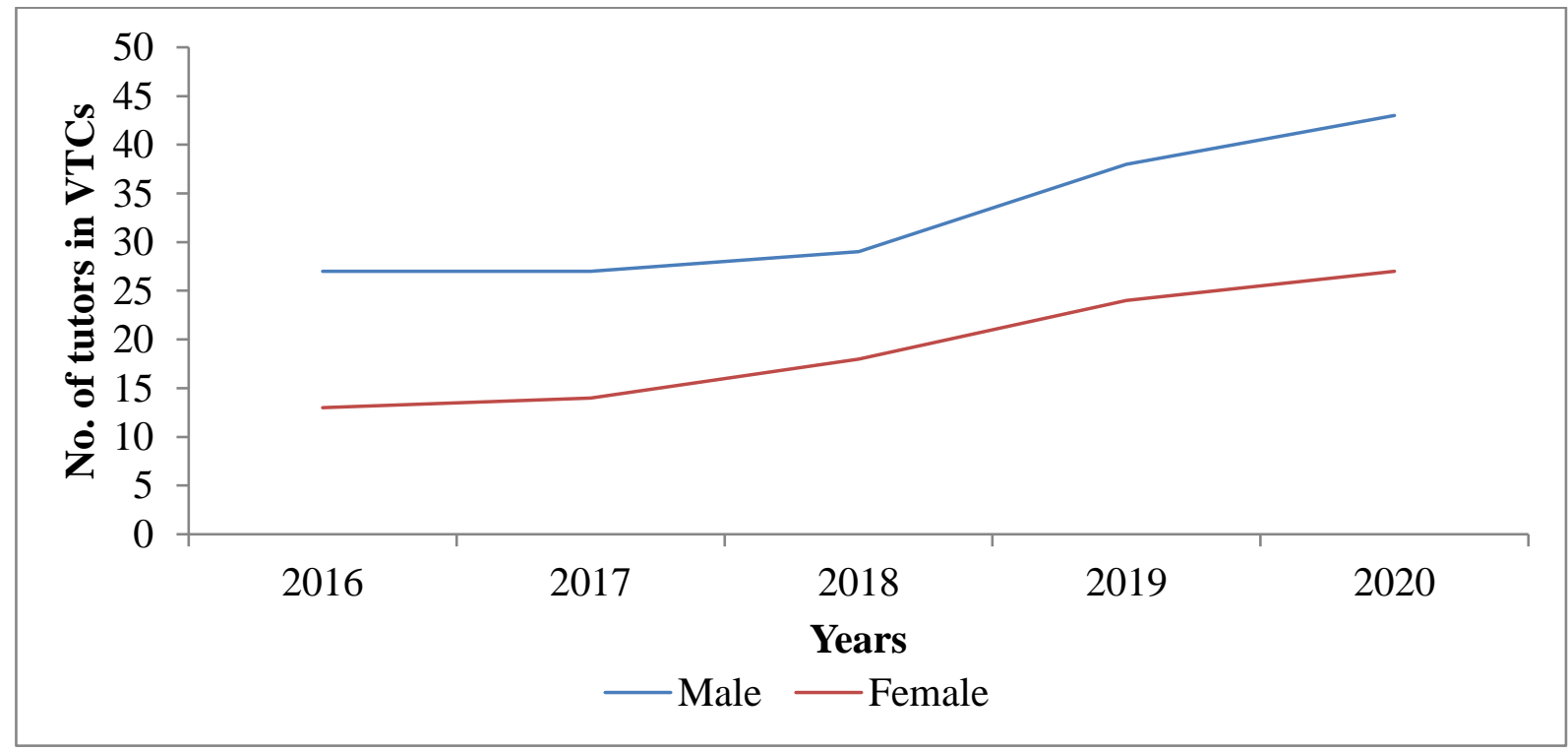

The data shows that there has been an increase in the distribution of tutors (both male and female) by the county government of West Pokot in the six VTCs. However, the distribution of male and female teachers in the VTCs has varied across the years with the employment of more male tutors compared to the females. Nevertheless, the county government has tried to bring equality in the profession since 2016; the percentage of male tutors was $67.5 \%$ against the female proportion of $32.5 \%$ (13 tutors). Over the next five years, by 2020, the proportion of female tutors increased to $38.6 \%$ (27 tutors) against $61.4 \%$ of male (43 tutors). This means that efforts are needed to ensure that both male and female tutors are given an opportunity in teaching in vocational training institutions. In support of this, Manager No. 6 indicated that the number of tutors in VTCs has been increasing over the last five years, but the number does not correspond with the number of students enrolled, leading to overcrowding in some courses.
Further, Figure 1 shows the number of female tutors is low compared to male tutors. Manager No. 1 said that:

The number of male tutors has always remained higher than the number of female tutors because most who apply for teaching positions are male compared to female.

To understand why there were more male tutors compared to various female factors were found to explain the trend as can be seen from the responses made below. At first, societal factors were also observed to play in determining the distribution and employment of female tutors in public VTCs as was indicated by Manager No. 3:

The trend is that male teaching staffs are more than female ones. This is because of the community attitude (negative) towards tutors in VTCs who are female. 
This means that qualified and competent female tutors have minimal chances of being hired to teach in VTCs compared to their male counterparts because of the societal beliefs that technical courses are for men compared to female. Those female tutors who are qualified may thus be discouraged to apply.

Another factor that could explain the low employment of female tutors in vocational training centres is the composition of the board. Most of the VTCs selection boards at the county level are mostly male-dominated. And these boards tend to employ male managers compared to female ones. For all the six VTCs in West Pokot County, none of the managers was female and this showed gender discrimination in the appointment of female tutors to senior vocational training institutions in the study area.

The lack of female tutors and managers was cited to affect the decision by potential girls to seek admission for various vocational training programmes by some of the VTCs managers interviewed. Their availability in the VTCs was cited to be key towards raising female students' enrolment. For instance, Manager No. 6 said that: ...definitely having more female staff members will increase the enrolment of female students. Female tutors will act as role models to their gender-girls.

Manager No. 2 also added that:

I believe this will attract female students due to the fact that female tutors will act as role models in the community.

In addition, Manager No. 1 observed that:

...yes, especially female tutors in maledominated courses. They will act as role models and attract female trainees into male-dominated STEM courses.

The above responses suggest that one aspect that VTCs board ensuring that they employ female tutors would go far in ensuring that female students enrol more in such institutions.

\section{The Admission Rate of Female Students in VTCs from 2016-2020}

The study also collected information on the admission rate of female students in VTCs over the period and the outcomes presented in Figure 2.

Figure 2: Admission rate of female students in VTCs from the year 2016-2020

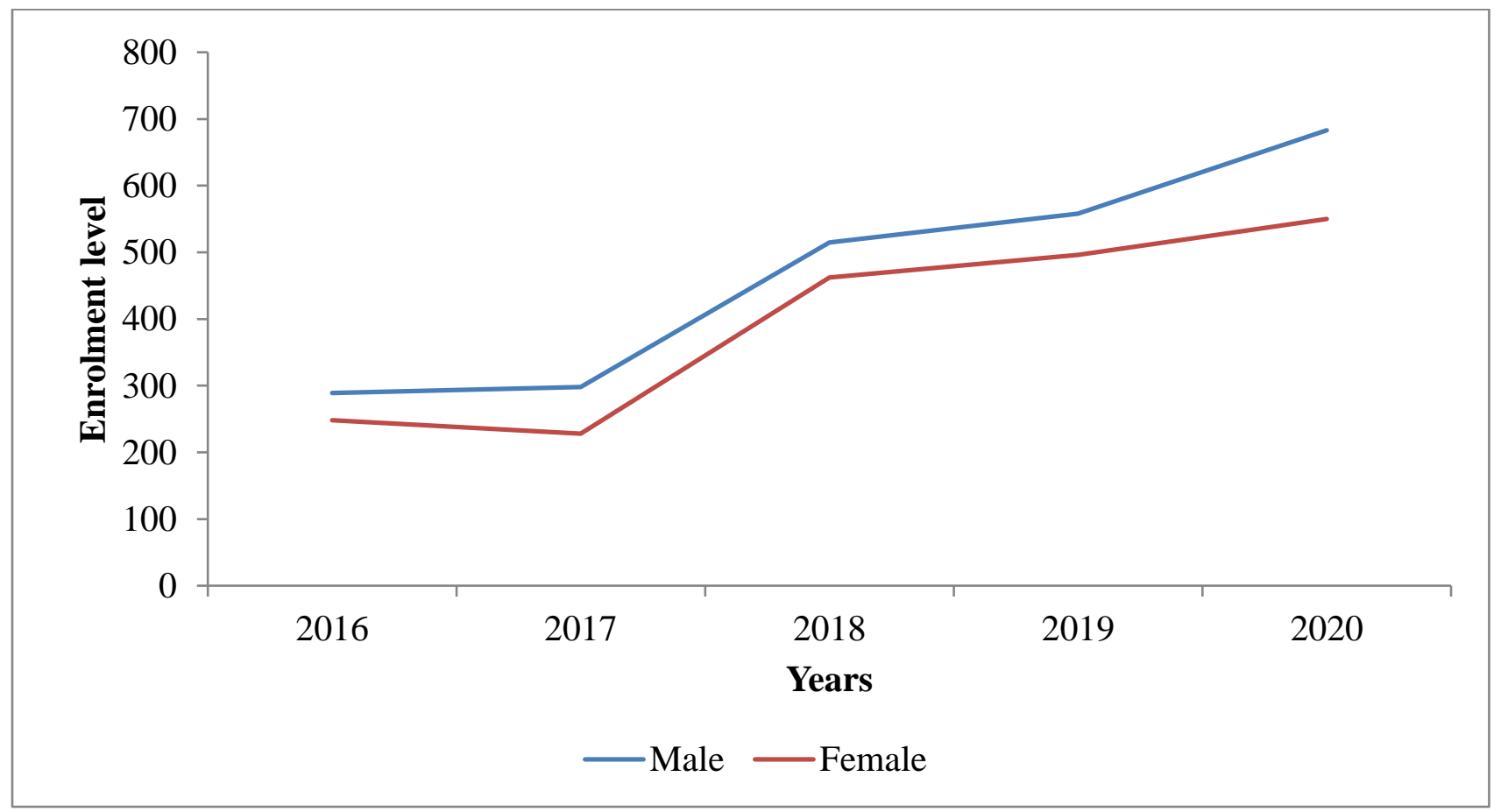


The figure above shows that there has been a steady increase in enrolment by both male and female students in vocational training programmes in the six west Pokot county institutions. The increased enrolment levels among students were explained by Manager No. 4 during the interview:

Due to bursary from the county government of West Pokot of 2019, capitation grants to VTCs really increased our institution enrolment a bit.

Manager No. 6 also mentioned that:

The increase in enrolment has been occasioned by the awareness of many students on the available opportunities in VTCs. Secondly, the government policy on $100.0 \%$ transition from all levels of education has resulted in increased enrolment in our institution.

Nevertheless, the admission of male students is higher compared to female students. For instance, the students admitted in 2016 were $53.8 \%$ male and $46.2 \%$ female. In the year 2020, male students' admission in VTC was $55.4 \%$, while female students were $44.6 \%$. The result means that despite increased efforts by various stakeholders to promote girls' access to vocational education, their admission rate is below that of boys in West Pokot. This issue of girls' low girl admission rate in VTCs was explained by Manager No. 3:

Caused by family responsibilities, fees challenge marriage and maternity leave.

This means that socioeconomic factors appear to be a hindrance to the enrolment of female students in vocational programmes.

Data on the completion rate of students enrolled in VTCs in the county was sought and presented in Figure 3.

\section{Figure 3: Completion rate of students in VTCs from 2016 - 2020}

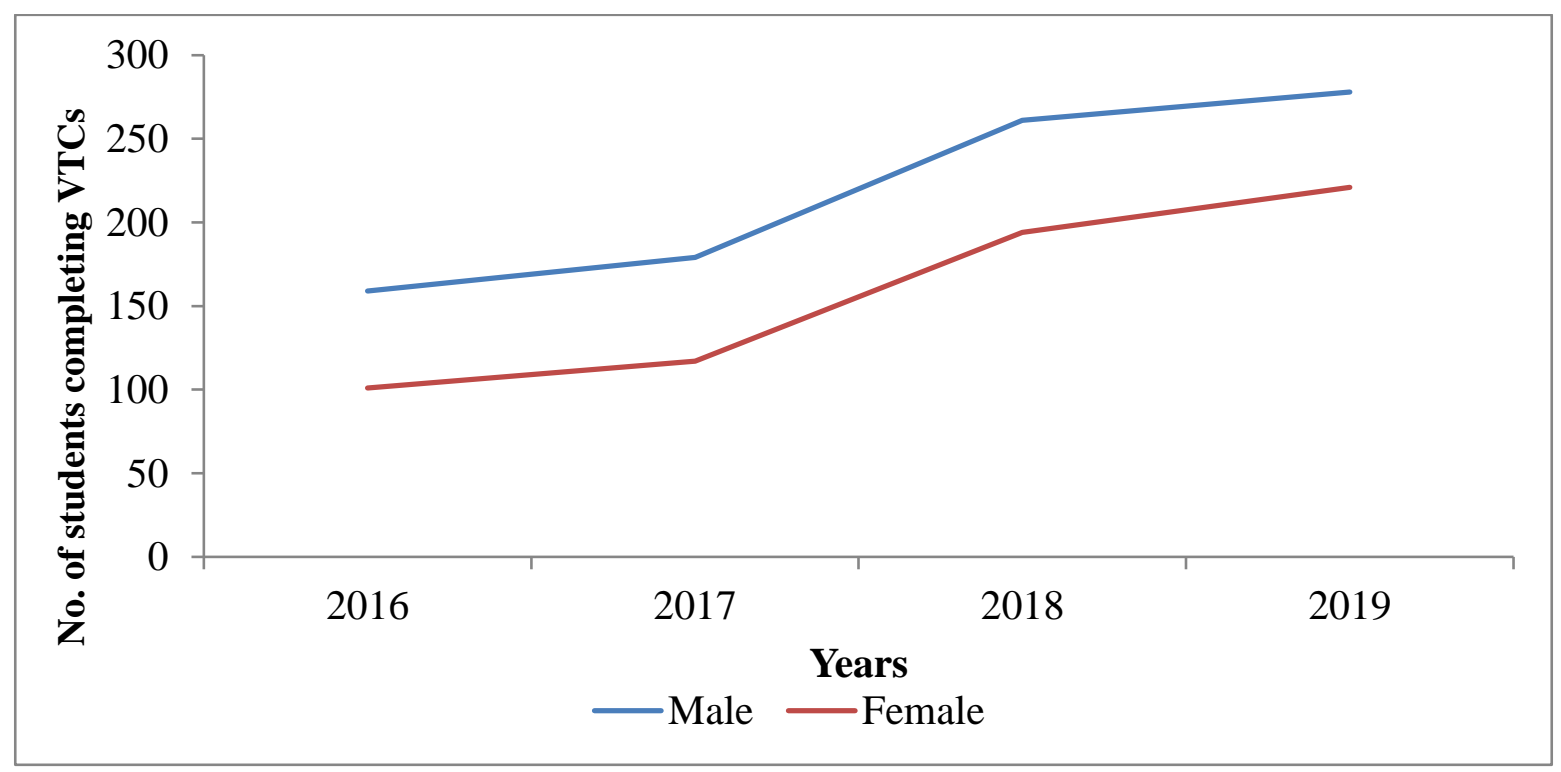

The result shows that there has been a steady increase in both male and female students' completion rate in the six VTCs in West Pokot County. Further, the data shows there have been significant gains in female students' completion rate over the years as it stood at $38.8 \%$ in the year 2016 compared to boys $(61.2 \%)$. However, by the year 2019 , the female students' completion rate against the boys was at $44.3 \%$ compared to boys $55.7 \%$.
This portrays a positive trajectory towards ensuring that female students enrolled to complete their various artisans and craft courses in the study area.

Despite positive completion rate figures for girls in VTCs, during an interview with some managers indicated that the rate of girls dropping out of VTCs was high in their institutions compared to male students. Manager No. 3 said that: 
...high dropout rate due to school fees challenges and huge family responsibility due to lack of property ownership as poverty is rampant.

This means that the high poverty rate affects girl child retention in vocational training programmes. When asked on the proportion of female students who are likely to drop out of school, most managers indicated that $45.0 \%$ or more of them are unlikely to finish their course as many end up getting married, others lose interest in schooling, others opt to seek work opportunities whereas others defer their studies for lack of support from the parents and community.

To understand the distribution of students based on their gender, data was collected on the number of students enrolled in various courses that were being offered in the six VTCs. The results of the analysis are presented in Table 1.

Table 1: Distribution of Students according to courses offered in VTCs

\begin{tabular}{|c|c|c|c|c|c|}
\hline Course(s) offered & Gender & $\begin{array}{l}\text { No. of VTCs } \\
\text { offering the } \\
\text { course }\end{array}$ & $\begin{array}{l}\text { Min } \\
\text { student } \\
\text { enrolled }\end{array}$ & $\begin{array}{l}\text { Max } \\
\text { student } \\
\text { enrolled }\end{array}$ & $\begin{array}{l}\text { Average } \\
\text { student } \\
\text { enrolled }\end{array}$ \\
\hline \multirow[t]{2}{*}{ Masonry (Building \& construction) } & Male & 6 & 5 & 101 & 44 \\
\hline & Female & 0 & 0 & 0 & 0 \\
\hline \multirow[t]{2}{*}{ Carpentry } & Male & 6 & 13 & 59 & 33 \\
\hline & Female & 1 & 1 & 1 & 1 \\
\hline \multirow{2}{*}{ Garment making (Fashion \& Design) } & Male & 3 & 2 & 5 & 4 \\
\hline & Female & 6 & 57 & 173 & 85 \\
\hline \multirow{2}{*}{ Plumbing } & Male & 2 & 13 & 43 & 28 \\
\hline & Female & 1 & 1 & 1 & 1 \\
\hline \multirow[t]{2}{*}{ Electrical \& electronics } & Male & 2 & 11 & 90 & 50 \\
\hline & Female & 1 & 6 & 6 & 6 \\
\hline \multirow{2}{*}{ Hairdressing \& beauty } & Male & 1 & 5 & 5 & 5 \\
\hline & Female & 3 & 22 & 46 & 30 \\
\hline \multirow[t]{2}{*}{ Motor Vehicle \& Mechanics } & Male & 3 & 13 & 29 & 22 \\
\hline & Female & 2 & 1 & 4 & 3 \\
\hline \multirow[t]{2}{*}{ ICT } & Male & 4 & 5 & 18 & 11 \\
\hline & Female & 4 & 13 & 27 & 19 \\
\hline \multirow{2}{*}{ Food \& Beverage } & Male & 0 & 0 & 0 & 0 \\
\hline & Female & 1 & 6 & 6 & 6 \\
\hline \multirow[t]{2}{*}{ Knitting } & Male & 0 & 0 & 0 & 0 \\
\hline & Female & 1 & 1 & 1 & 1 \\
\hline \multirow[t]{2}{*}{ Leatherwork } & Male & 1 & 15 & 15 & 15 \\
\hline & Female & 1 & 18 & 18 & 18 \\
\hline \multirow[t]{2}{*}{ Driving } & Male & 1 & 53 & 53 & 53 \\
\hline & Female & 1 & 7 & 7 & 7 \\
\hline \multirow[t]{2}{*}{ Welding \& fabrication } & Male & 1 & 31 & 31 & 31 \\
\hline & Female & 0 & 0 & 0 & 0 \\
\hline
\end{tabular}

The data provided in Table 1 illustrates the enrolment of students (male and female) on various artisans and crafts courses in the vocational training centres. Due to the perceptions that many in society have towards certain courses belonging to a particular gender, this is seen to be reflected in the admission rate. For instance, from the six institutions, no female candidate has enrolled in a building and construction course (masonry) because society perceives it to be a masculine career. Using the education progression structure in Kenya, when one undertakes a certificate/artisan/craft course in building and construction, he/she can pursue further education (diploma, degree and the rest) until he/she can become an engineer in the future. This aspect of considering that some courses (associated with 
STEM) are masculine prevents many potential students from applying for them in the study area. The other courses that recorded no female student enrolment from the six institutions were; welding and fabrication. Further, the following courses recorded low enrolment of female students; plumbing (1), carpentry (1), electrical and electronics (6), motor vehicle mechanics (4) and driving (7). On the STEM, only technology courses were found to attract female students (27) compared to male (18) in West Pokot County. On the nonSTEM courses, the society perceived the following courses to pursue by female students, and that is why they registered higher enrolment compared to male students: garment making, tailoring, fashion and design (173), hairdressing and beauty (46), food and beverage (6) and knitting (1). This means that female student' opportunities to participate in science, mathematics and engineering courses are limited in vocational training institutions in West Pokot County, Kenya.

The researcher further enquired to know why the rate of female students being enrolled, retained or complete their education was lower than their male counterparts. Manager No. 5 provided the following response:

\section{Inadequate financial support in catering for} their examination fees

Another Manager No. 4 said that lack of school fees and early pregnancies were some of the challenges that affected female students' participation in vocational education and training in West Pokot County, Kenya.

\section{CONCLUSIONS}

This paper investigated the female students' participation in technical vocational education and training in West Pokot County, Kenya. Evidence presented in this paper has shown that there has been a steady increase in enrolment of both male and female students in vocational institutions, but comparison across gender shows disparities where female enrolment in VTCs appears to be low. This is also compounded by a low number of tutors employed to teach in public VTCs in the study area and it emerged that this was a factor that resulted in low attraction to VTCs by female students. Despite government policy providing equal opportunities for both genders in pursuing relevant science, technology, engineering and mathematical programmes, it was found out that STEM courses were less attractive to female students. Only technology courses were found to have a higher proportion of female students compared to male. This meant that the majority of girls in West Pokot County miss out on the opportunities available for girls in the current century due to societal and economic factors that inhibit them from gaining knowledge and skills on vocational and technical education. With this in mind, the majority of girls appear to stick to undertake courses that the society considered to be 'feminine' like dressmaking, beauty, food and beverage and less on 'masculine' courses like building and construction, plumbing, electrical and electronics, among others.

\section{RECOMMENDATIONS}

To ensure effective participation of girls to acquire $21^{\text {st }}$-century skills in technical and vocational education, the following recommendations are made to a wide range of stakeholders:

(a) There is a need for both the Kenyan national and the West Pokot county governments to provide adequate financial and infrastructural support to public vocational training centres to make them capable of admitting more girls, including female candidates who may wish to pursue their various artisans and crafts courses there

(b)Due to the high poverty index among households in West Pokot County, there is a need for girls to be provided with full scholarships to undertake various vocational training programmes available. This would result in increased admission, retention and completion rates for girls.

(c) There is a need for public awareness of the opportunities provided at vocational training centres for the girl child. This will diffuse the negative perceptions that communities have on girls undertaking various vocational training programmes. Further, regular workshops are needed at primary and secondary school levels to educate girls on the importance of vocational skills in the $21^{\text {st }}$ century. 
(d)There is a need for the West Pokot county government to build more hostels for girls for accommodation purposes.

(e) The West Pokot County need to ensure that they have in place gender mainstreaming policies when hiring tutors and managers of vocational training centres.

\section{REFERENCES}

Adewale, P. O., \& Adhuze, O. O. (2017). Factors affecting polytechnic students' perception of building-based vocational skills. International Journal of Vocational Education and Training Research, 3(4), 29 - 35.

Azubuike, O. C. (2011). Influential factors affecting the attitude of students towards vocational/technical subjects in secondary schools in Southeastern Nigeria. Journal of educational and social research, 1(2), 49-49.

Institute of Economic Affairs (2017). Youth polytechnic students' perception of vocational training in Nakuru County. Nairobi: Institute of Economic Affairs.

International Labour Organisation, (2015). World employment social outlook: The changing nature of jobs. Geneva: International Labour Office Research Department.

Lugga, A. A. \& Umoh, E. A. (2018). TVET institutions, sustainable development goals and women and youth empowerment in Rural Zamfara North, Nigeria. A paper presented at the 13th International Conference and Exhibition on Power and Telecommunication (ICEPT 2017), Abuja, Nigeria, 9th - 13th October 2018.

Patrick, L. E., Maureen, O. A., \& Lucas, O. (2015). Enrolment Trends in Youth Polytechnics in West Pokot County, Kenya. Journal of Education and Practice, 6(10), 110-117.

Ngugi, M. \& Muthima, P. (2017). Female participation in technical, vocational education and training institutions (TVET) subsector: The Kenyan experience. Public Policy and Administration Research, 7(4), 9-23.
Opwora, M. C. (2013). Influences on gender disparity in TVET Enrolment: A comparison of engineering and business courses in Kenya. D.Phil Thesis, University of Newcastle, New South Wales Australia.

Patrick, L. E., Maureen, O. A., \& Lucas, O. (2015). Enrolment Trends in Youth Polytechnics in West Pokot County, Kenya. Journal of Education and Practice, 6(10), 110-117.

Republic of Kenya (2007). Kenya Vision 2030. Nairobi: Government Printer.

Serem, D. (2014). An analysis of gender enrolment trends in youth polytechnics: a case of Cheptarit Youth Polytechnic, Kenya. Retrieved on 30-082020 from http://rvti.ac.ke/downloads/KJ-TVE T\%20VOL\%202.pdf\#page $=61$

UNESCO (2016). Women must be fully engaged in Technical and Vocational Education and Training. Retrieved online on 23-08-2020 from https://en.unesco.org/news/women-must-befully-engaged-technical-and-vocationaleducation-and-training

United Nations (2015a). Addis Ababa agenda of the third international conference on financing for development. New York: United Nations.

United Nations (2015b). The 17 sustainable development goals (SDGs) to transform our world. New York: United Nations. Retrieved online on 20-08-2020 from https://www/sdgs.un .org/goals 